\title{
YACON PRODUCTION AT DIFFERENT PLANTING SEASONS AND GROWING ENVIRONMENTS
}

\author{
PRODUÇÃO DE YACON EM DIFERENTES ESTAÇÕES DE PLANTIO E \\ AMBIENTES DE CULTIVO
}

\author{
Diego Mathias Natal da SILVA ${ }^{1}$, Fábio Luiz de OLIVEIRA ${ }^{2}$, \\ Mateus Augusto Lima QUARESMA ${ }^{3}$, Wellington Abeldt ERLACHER ${ }^{4}$, \\ Tiago Pacheco MENDES 5
}

1. Post doctorate in Plant Production of Centro de Ciências Agrárias e Engenharias da Universidade Federal do Espírito Santo - CCAE / UFES, Alegre, ES, Brazil. diegoufvjm@ @ahoo.com.br; 2. PhD in Plant Science, Teacher of the CCAE / UFES, Alegre, ES, Brazil; 3. $\mathrm{PhD}$ in Plant Production of the CCAE / UFES, Alegre, ES, Brazil; 4. Master in Plant Production of the CCAE / UFES, Alegre, ES, Brazil; 5. Master student in Plant Production of the CCAE / UFES, Alegre, ES, Brazil.

\begin{abstract}
Yacon is a functional food with great potential for horticultural exploitation and its cultivation demands the generation of agronomic information. To address these needs, this study was performed to evaluate the production of yacon planted in different planting seasons under two growing conditions in Brazil. The experiments were conducted in two different locations, one in the mountain region (tropical microclimate at altitude with milder temperatures) and the other in the lowland region (warm tropical microclimate with higher temperatures). At both sites, yacon was planted in four seasons: autumn (April), winter (July), spring (September) and summer (December). At harvest, the tuberous roots were evaluated for leaf area index and the variables of vegetative development and productivity of plants (for total and standard commercial roots). It was concluded that yacon cultivation in mountain conditions (tropical climate with milder temperature) promotes the development and production of yacon. Additionally, planting in the autumn for both growing conditions (mountain or lowland) promotes the development and production of yacon, including increased production of roots of better commercial grade, allowing greater economic profitability. These results indicate that temperature has an influence on the growth and yield of the tuberous roots of yacon, and milder temperatures were more favourable.
\end{abstract}

KEYWORDS: Smallanthus sonchifolius. Polymnia sonchifolia. Tuberous root. Yield. Temperature.

\section{INTRODUCTION}

The search for a healthier diet has increased the demand for functional foods, which is a new category of foods that adds high quality sensory, nutritional, and health benefits (ZERAIK et al., 2010). The yacon (Smallanthus sonchifolius) is part of this category of functional foods due to its composition of bioactive elements such as the inulin-type fructans and fructooligosaccharides (FOS), which offer many health benefits (OJANSIVU et al., 2011). Yacon is a plant of the Asteraceae family of Andean origin that shows possibilities of adaptation to the climate and soil. Its resistance to cold and drought is related to the large amount of reserve carbohydrates in the subterranean organs (SANTANA; CARDOSO, 2008).

In the last three decades, yacon cultivation has spread to other continents, and yacon is now cultivated in many countries outside the Andes, such as Paraguay, the United States, Slovakia, China, Korea, Taiwan and Brazil (LACHAN et al., 2004). The migratory route that the plant followed was fully identified. In the 1980s, yacon left for the first time from Ecuador to New Zealand, where it adapted well and where it is now cultivated on a small scale (MANRIQUE; HERMANN, 2004). In 1985, he was taken from New Zealand to Japan, where he has carried out the largest amount of scientific research related to agronomic management, chemical composition, health properties and the development of processed products (LACHAN et al., 2004). From Japan, root dispersal began in other countries, such as Korea and Brazil as a promising plant for consumption and cultivation (SEMINARIO et al., 2003).

Yacon was introduced in Brazil in the early 1990s and has developed well under the country's climate conditions, where consumption increased in the mid-2000s and the root became popularly known as potato yacon or diet potato (SANTANA; CARDOSO, 2008). The areas where the plant is cultivated in Brazil are generally restricted to the State of São Paulo, mainly in the municipality of Capão Bonito (KAKIHARA et al., 1996), and recently in the vegetable growing regions of Brasília 
and the states of Espírito Santo, Rio de Janeiro and Minas Gerais (SANTANA; CARDOSO, 2008, MAIER, 2012).

Yacon consumption provides several benefits including prebiotic effects (Soleimani et al., 2012), protection against colon cancer (MOURA et al., 2012), intestinal regulation (ALBUQUERQUE; ROLIM, 2011), immune stimulation (VAZTOSTES et al., 2014), reduction of serum lipids (HABIB et al., 2011) and modulation of basal insulin (GENTA et al., 2009). Yacon consumption also has effects on the control of chronic diseases such as diabetes (OLIVEIRA et al., 2013). These characteristics have attracted the interest of society, increasing food and pharmaceutical consumption as well as industrialization of yacon (GUSSO et al., 2015).

This growing interest has generated demand for technologies for yacon cultivation. However, little information on strategies for yacon cultivation is available, which is likely why the species has had such varied productive performance. Studies carried out in several countries, such as Korea, Ecuador, Japan, Peru, the Czech Republic and the United States, indicate yields of tuberous roots between 25.6 and $119 \mathrm{t} \mathrm{ha}^{-1}$ (DOO et al., 2001; FERNANDEZ et al., 2006; NIETO, 1991; OGISO et al., 1990; SEMINARIO et al., 2003; SUMIYANTO et al., 2012). In Brazil, Oliveira and Nishimoto (2004) obtained yields of tuberous roots up to $45 \mathrm{t} \mathrm{ha}^{-1}$ in Botucatu, São Paulo state, and Kakihara et al. (1996) obtained $100 \mathrm{t} \mathrm{ha-}^{1}$ in Capão Bonito region, São Paulo state.

One factor that may affect yacon production performance is the season when the plant is grown. According to Seminario et al. (2003), in the Andes, yacon can be grown all year long provided irrigation is used. However, planting should be done during the rainy season. The authors report that optimal yacon development occurs between 18 and $25{ }^{\circ} \mathrm{C}$. However, yacon leaves can tolerate high temperatures without damage symptoms if soil moisture is adequate. Nevertheless, low night temperature seems to be necessary for the proper formation of tuberous roots.

The growth location influences the production of yacon because the time required for the plant to reach physiological maturity may vary between 6 and 10 months after planting when flowering begins. This time depends on the region and the season when yacon is grown. At lower elevation, maturity can be advanced (SANTANA; CARDOSO, 2008).

Agronomic information on yacon is very important, mainly because of the growing interest for its exploitation as a new product (GUSSO et al., 2015). Information on agronomic management is still rare, especially in Brazil.

Therefore, this study aimed to evaluate the growth and productivity of yacon in different planting seasons grown at two local conditions in Brazil.

\section{MATERIAL AND METHODS}

The experiments were conducted at two sites in southern Espirito Santo state, Brazil, from April 2013 to April 2014, with one site in mountain conditions in the Ibatiba municipality $\left(20^{\circ} 17 ' \mathrm{~S}\right.$; $41^{\circ} 37 \mathrm{~W}$; altitude of $837 \mathrm{~m}$ ) and the other site in lowland conditions in the Alegre municipality $\left(20^{\circ} 45 ' \mathrm{~S} ; 41^{\circ} 29^{\prime} \mathrm{W}\right.$; altitude of $\left.113 \mathrm{~m}\right)$.

The climate in southern Espirito Santo is similar to "Aw", with two seasons well defined during the year, a hot and rainy season between the months of October and March and another cold and dry season between the months of April and September; annual rainfall is approximately 1200 $\mathrm{mm}$. However, there are micro-regions due to the relief, which mainly influences the temperatures. The South Serrana micro-region (including the municipality of Ibatiba) is characterized by a mountain microclimate (tropical at altitude) with milder temperatures, and the Valley of the Itapemirim River (including the municipality of Alegre) is characterized by tropical hot microclimate (lowland) with higher temperatures (PEZZOPANE et al., 2012).

Precipitation and monthly averages of maximum and minimum temperature were obtained through automatic weather stations closest to the experiment, including INMET in the municipality of Alegre $\left(20^{\circ} 45^{\prime} \mathrm{S} ; 41^{\circ} 29^{\prime} \mathrm{W}\right.$; altitude of $\left.138 \mathrm{~m}\right)$ and INCAPER in the municipality of Iúna $\left(20^{\circ} 21^{\prime} \mathrm{S}\right.$, $41^{\circ} 33^{\prime} \mathrm{W}$; altitude of $758 \mathrm{~m}$ ) (Figure 1).

The soil of both sites was classified as RedYellow Latosol (Brazilian Classification System) (Embrapa, 2014) or as clayey Oxisol, Typic Haplustox (Soil Taxonomy, USDA classification), with medium texture (sand $68 \%$, silt $4 \%$, and clay $28 \%$ ) in the mountain condition and clayey soil (sand $60 \%$, silt $5 \%$, and clay $35 \%$ ) in the lowland. Samples of these soils collected at $0-20 \mathrm{~cm}$ were analysed. Soil in the mountain conditions had the following characteristics: $\mathrm{pH}$ (water) - 6.20; Phosphorus Mehlich 1 - $53.99 \mathrm{mg} \mathrm{dm}^{-3}$; Potassium $80.00 \mathrm{mg} \mathrm{dm}^{-3}$; Calcium - $2.12 \mathrm{cmol}_{\mathrm{c}} \mathrm{dm}^{-3}$; Magnesium - $0.87 \mathrm{cmol}_{\mathrm{c}} \mathrm{dm}^{-3}$; Aluminium - 0.0 $\mathrm{cmol}_{\mathrm{c}} \mathrm{dm}^{-3}$; Sum of basis - $3.24 \mathrm{cmol}_{\mathrm{c}} \mathrm{dm}^{-3}$; Effective CTC $-3.24 \mathrm{cmol}_{\mathrm{c}} \mathrm{dm}^{-3}$; Total organic 
carbon $-1.83 \%$; and Total nitrogen $-0.15 \%$. Soil in the lowland conditions had the following characteristics: $\mathrm{pH}$ (water) - 6.37; Phosphorus Mehlich 1 - $36.99 \mathrm{mg} \mathrm{dm}^{-3}$; Potassium - $57.00 \mathrm{mg} \mathrm{dm}^{-3}$; Calcium - $1.50 \mathrm{cmol}_{\mathrm{c}} \mathrm{dm}^{-3}$; Magnesium - 0.71 $\mathrm{cmol}_{\mathrm{c}} \mathrm{dm}^{-3}$; Aluminium - $0.0 \mathrm{cmol}_{\mathrm{c}} \mathrm{dm}^{-3}$; Sum of basis - $2.36 \mathrm{cmol}_{\mathrm{c}} \mathrm{dm}^{-3}$; Effective CTC $-2.36 \mathrm{cmol}_{\mathrm{c}}$ $\mathrm{dm}^{-3}$; Total organic carbon $-1.08 \%$; and Total nitrogen $-0.10 \%$.

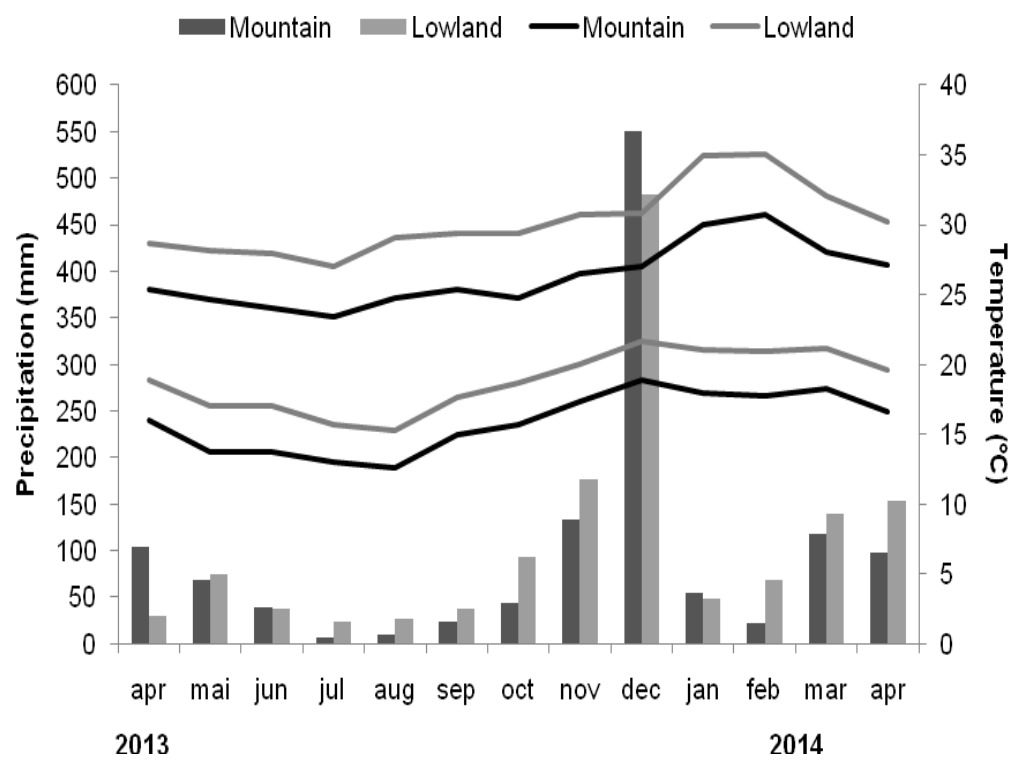

Figure 1. Precipitation and monthly temperature average, maximum and minimum observed during the assessments in mountain and lowland in the state of Espirito Santo, Brazil. Source: Incaper (2014).

In each growing environments, the experiment was conducted using a design of randomized blocks with four replicates. The treatments consisted of four planting seasons carried out in 2013: autumn (April), winter (July), spring (September) and summer (December).

The experimental unit consisted of five planting lines of $4 \mathrm{~m}$, with spacing of $1.0 \mathrm{~m}$ between lines and $0.5 \mathrm{~m}$ between plants, totalling eight plants of yacon per planting line. However, only ten plants harvested in the three centre lines, except for the borders, were used for data collection, i.e., only ten core plants of each plot represent the usable area.

In each culture condition the soil was prepared by ploughing to a depth of $30 \mathrm{~cm}$ followed by harrowing. The planting was carried out in furrows using rhizophores of approximately $35 \mathrm{~g}$ to a depth of $10 \mathrm{~cm}$, following the desired spacing. Then, $180 \mathrm{~g}$ of tanned cattle manure was applied. The cattle manure consisted of the following nutrients: $14.21 \mathrm{~g} \mathrm{~kg}^{-1} \mathrm{~N}, 4.75 \mathrm{~g} \mathrm{~kg}^{-1} \mathrm{P}, 5.28 \mathrm{~g} \mathrm{~kg}^{-1}$ $\mathrm{K}, 4.29 \mathrm{~g} \mathrm{~kg}^{-1} \mathrm{Ca}$ and $1.92 \mathrm{~g} \mathrm{~kg}^{-1} \mathrm{Mg}$. Throughout the growing cycle, weed control and conventional sprinkler irrigation, with an application rate of 30 mm weekly, were carried out.

At the time of flowering, when more than $80 \%$ of the stand was in full bloom, the crop was harvested. The harvests occurred in the mountain condition 270 days after planting (DAP) in autumn (in January 2014), 240 DAP in winter and 180 DAP in spring (both in March 2014), and in lowland conditions at 240 DAP in autumn (December, 2013), 180 DAP in winter (January, 2014) and 210 DAP in spring (April, 2014). At harvest, the number of leaves per plant; leaf area index; plant height; stem diameter; number of stems per plant; leaf, stem, rhizophore, tuberous root and total dry mass; rhizophore fresh mass; and large, medium, small and full tuberous root yields were all evaluated.

Height was measured with the aid of a measuring tape, from ground level to the apex of the highest stem. Diameter was measured with the aid of a caliper for this same stem, and the number of stems was measured considering those that sprang directly from the rhizophore planted or those that presented with more than three pairs of leaves. Leaf area was obtained using a photoelectric meter Licor Area Meter 3100 (LiCor, EUA). Dry mass was obtained after each part of the plant was dried in a kiln with forced air circulation at $70 \pm 5^{\circ} \mathrm{C}$ until reaching constant mass.

Tuberous root classifications were adapted from Seminario et al. (2003) and included classes for length, diameter and weight of the tuberous 
roots. Thus, harvested roots were classified as large (length greater than $20 \mathrm{~cm}$, diameter greater than 7 $\mathrm{cm}$ and weight greater than $300 \mathrm{~g}$ ), medium (length between 12 and $20 \mathrm{~cm}$, diameter between 5 and 7 $\mathrm{cm}$ and weight between 120 and $300 \mathrm{~g}$ ), or small (length less than $12 \mathrm{~cm}$, diameter less than $5 \mathrm{~cm}$ and weight less than $120 \mathrm{~g}$ ).

Leaf area data, fresh mass and dry mass were converted into biomass per land area and leaf area index considering the plant density of each plot (2 plants $\mathrm{m}^{-2}$ ).

Statistical analyses were carried out using the statistical software Genes (CRUZ, 2006). Data were subjected to analysis of joint variance involving both growing environments (mountain and lowland) by $\mathrm{F}$ test at $5 \%$ probability and comparison of means by Tukey test at 5\% probability.

\section{RESULTS}

For both growing environments, mountain and lowland, the emergence and growth of yacon shoots in the summer planting was not satisfactory, so the assessments are presented for the other planting seasons.

For foliar characteristics of yacon, the joint analysis of variance revealed that there was no significant interaction between the growing conditions and planting season, showing that the effect of these sources of variation occurred independently. However, for the other variables, significant interactions were observed between the growing conditions and planting season (Table 1).

Table 1. Summary analysis of joint variance for yacon characteristics analyzed.

\begin{tabular}{|c|c|c|c|c|}
\hline \multirow[b]{2}{*}{ Characteristics } & \multicolumn{3}{|c|}{ Source of variation (probability) } & \multirow[b]{2}{*}{$\mathrm{CV} \%$} \\
\hline & Planting seasons (PS) & $\begin{array}{l}\text { growing environments } \\
(\mathrm{GE})\end{array}$ & PS x GE & \\
\hline Number of leaves per plant & $100.00^{\mathrm{ns}}$ & $11.73^{\mathrm{ns}}$ & $21.10^{\mathrm{ns}}$ & 12.91 \\
\hline Leaf area index & $2.13 *$ & $0.19 * *$ & $100.00^{\mathrm{ns}}$ & 27.03 \\
\hline Leaf dry mass & $0.20 * *$ & $0.01 * *$ & $100.00^{\mathrm{ns}}$ & 20.24 \\
\hline Plant height & $0.01 * *$ & $3.42 *$ & $0.01 * *$ & 7.99 \\
\hline Stem diameter & $0.01 * *$ & $0.04 * *$ & $1.70 *$ & 11.06 \\
\hline Number of stems per plant & $0.53 * *$ & $0.14 * *$ & $4.65^{*}$ & 17.11 \\
\hline Rhizophore fresh mass & $0.01 * *$ & $0.03 * *$ & $0.02 * *$ & 16.53 \\
\hline Stem dry mass & $0.01 * *$ & $0.01 * *$ & $0.54 * *$ & 16.59 \\
\hline Rhizophore dry mass & $0.01 * *$ & $0.01 * *$ & $0.41 * *$ & 21.63 \\
\hline Tuberous root dry mass & $0.11 * *$ & $0.01 * *$ & $4.86^{*}$ & 16.82 \\
\hline Total dry mass & $0.01 * *$ & $0.08 * *$ & $0.78 * *$ & 14.10 \\
\hline Large tuberous root yield & $0.01 * *$ & $0.01 * *$ & $2.56^{*}$ & 23.67 \\
\hline Medium tuberous root yield & $1.08 *$ & $0.01 * *$ & $0.05 * *$ & 31.30 \\
\hline Small tuberous root yield & $5.25^{\mathrm{ns}}$ & $0.29 * *$ & $0.05 * *$ & 13.57 \\
\hline Total tuberous root yield & $0.01 * *$ & $0.01 * *$ & $0.73 * *$ & 10.36 \\
\hline
\end{tabular}

** Significant at $1 \%$ probability; * Significant at 5\% probability; ${ }^{\mathrm{ns}}$ não significant by $\mathrm{F}$ test, respectively.

The number of leaves was not influenced by growing conditions or by planting season, unlike the leaf area index (LAI) and leaf dry mass, which were influenced both by the growing conditions and the planting season, with higher values being observed in the mountains and autumn planting, respectively. Notably, the LAI of the spring planting did not differ from that of the autumn planting (Table 2).

Table 2. Leaf characteristics of yacon grown in two environments and three planting seasons.

\begin{tabular}{lccc} 
& Number of leaves per plant & $\begin{array}{c}\text { Leaf area index }\left(\mathrm{m}^{2}\right. \\
\left.\mathrm{m}^{-2}\right)\end{array}$ & Leaf dry mass $\left(\mathrm{Mg} \mathrm{ha}^{-1}\right)$ \\
\hline Growing environments & & & \\
\hline Mountain & $73.04 \mathrm{a}^{1}$ & $2.85 \mathrm{a}$ & $1.91 \mathrm{a}$ \\
Lowland & $62.76 \mathrm{a}$ & $2.13 \mathrm{~b}$ & $1.34 \mathrm{~b}$ \\
\hline Planting seasons & & & \\
\hline Autumn & $65.02 \mathrm{a}^{1}$ & $3.12 \mathrm{a}$ & $2.17 \mathrm{a}$ \\
Winter & $70.19 \mathrm{a}$ & $1.79 \mathrm{~b}$ & $1.23 \mathrm{~b}$ \\
Spring & $68.50 \mathrm{a}$ & $2.56 \mathrm{ab}$ & $1.49 \mathrm{~b}$
\end{tabular}

${ }^{1}$ Means followed by the same letters, vertically, are not different by $\mathrm{F}$ test for growing environments and Tukey test for planting seasons, both at $5 \%$ probability. 
Regarding growing conditions, higher fresh mass rhizophores and larger diameters and numbers of stems were observed in plants grown in the lowland. Only the height of the plants grown in mountains was higher (Table 3).

Table 3. Biometric characteristics of yacon grown in two environments and three planting seasons.

\begin{tabular}{|c|c|c|c|c|}
\hline \multirow[t]{2}{*}{ Planting season } & \multicolumn{4}{|c|}{ Growing environments } \\
\hline & Mountain & Lowland & Mountain & Lowland \\
\hline & \multicolumn{2}{|c|}{ Plant height $(\mathrm{cm})$} & \multicolumn{2}{|c|}{ Stem diameter $(\mathrm{cm})$} \\
\hline Autumn & $173.06 \mathrm{a}^{1}$ & $203.75 \mathrm{a}$ & $2.13 \mathrm{a}$ & $2.85 \mathrm{a}$ \\
\hline Winter & $170.75 \mathrm{a}$ & $152.83 \mathrm{~b}$ & $2.00 \mathrm{ab}$ & $2.33 \mathrm{~b}$ \\
\hline Spring & $139.31 \mathrm{~b}$ & $89.56 \mathrm{c}$ & $1.68 \mathrm{~b}$ & $1.61 \mathrm{c}$ \\
\hline \multirow[t]{2}{*}{ Means } & $161.04 \mathrm{~A}^{2}$ & $148.71 \mathrm{~B}$ & $1.94 \mathrm{~B}$ & $2.26 \mathrm{~A}$ \\
\hline & \multicolumn{2}{|c|}{ Number of stems per plant } & \multicolumn{2}{|c|}{ Rhizophore fresh mass $\left(\mathrm{Mg} \mathrm{ha}^{-1}\right)$} \\
\hline Autumn & $6.00 \mathrm{~b}$ & $9.92 \mathrm{a}$ & $10.80 \mathrm{a}$ & $25.25 \mathrm{a}$ \\
\hline Winter & $4.69 \mathrm{~b}$ & $6.58 \mathrm{~b}$ & $6.11 \mathrm{~b}$ & $18.78 \mathrm{~b}$ \\
\hline Spring & $8.25 \mathrm{a}$ & $8.38 \mathrm{ab}$ & $7.92 \mathrm{ab}$ & $10.14 \mathrm{c}$ \\
\hline Means & $6.31 \mathrm{~B}$ & $8.29 \mathrm{~A}$ & $8.28 \mathrm{~B}$ & $18.06 \mathrm{~A}$ \\
\hline
\end{tabular}

${ }^{1}$ Vertically, the average seasons planting within each growing condition followed by the same lowercase letters do not differ by Tukey test at $5 \%$ probability; ${ }^{2}$ Horizontally compares means between the growing environments for each variable, where the same capital letters do not differ by $\mathrm{F}$ test at $5 \%$ probability.

Considering the planting seasons in each condition of farming, in the mountains, there was a greater height and diameter of yacon stems planted in the autumn, which did not differ from the winter planting. Higher fresh mass of rhizophores was also observed in the autumn planting, which did not differ from spring planting, which in turn had a higher number of stems per plant (Table 3 ).

In the lowlands, decreasing values of height, stem diameter and fresh mass of rhizophores were observed as planting approached the summer, and thus higher values were observed in the autumn planting than in the spring planting. Increased numbers of stems per plant were also observed in the autumn planting, which in turn did not differ from the spring planting (Table 3 ).

In plants grown under lowland conditions, higher accumulation of stem and rhizophore dry masses were observed; however, higher accumulation of tuberous root and total dry masses were observed in plants grown in the mountains (Table 4).

Table 4. Organs and total dry mass of yacon grown in two environments and three planting seasons.

\begin{tabular}{|c|c|c|c|c|}
\hline \multirow{2}{*}{$\begin{array}{l}\text { Planting } \\
\text { seasons }\end{array}$} & \multicolumn{4}{|c|}{ Growing environments } \\
\hline & Mountain & Lowland & Mountain & Lowland \\
\hline & \multicolumn{2}{|c|}{$\operatorname{Stem}\left(\mathrm{Mg} \mathrm{ha}^{-1}\right)$} & \multicolumn{2}{|c|}{ Rhizophore $\left(\mathrm{Mg} \mathrm{ha}^{-1}\right)$} \\
\hline Autumn & $4.34 \mathrm{a}^{1}$ & $7.34 \mathrm{a}$ & $1.87 \mathrm{a}$ & $3.89 \mathrm{a}$ \\
\hline Winter & $2.69 \mathrm{~b}$ & $4.99 \mathrm{~b}$ & $1.07 \mathrm{a}$ & $2.63 \mathrm{~b}$ \\
\hline Spring & $2.79 \mathrm{~b}$ & $2.86 \mathrm{c}$ & $1.37 \mathrm{a}$ & $1.57 \mathrm{c}$ \\
\hline \multirow[t]{2}{*}{ Means } & $3.27 \mathrm{~B}^{2}$ & $5.06 \mathrm{~A}$ & $1.44 \mathrm{~B}$ & $2.70 \mathrm{~A}$ \\
\hline & \multicolumn{2}{|c|}{ Tuberous root $\left(\mathrm{Mg} \mathrm{ha}^{-1}\right)$} & \multicolumn{2}{|c|}{ Total $\left(\mathrm{Mg} \mathrm{ha}^{-1}\right)$} \\
\hline Autumn & $9.28 \mathrm{a}$ & $4.91 \mathrm{a}$ & $17.85 \mathrm{a}$ & $18.11 \mathrm{a}$ \\
\hline Winter & $8.30 \mathrm{ab}$ & $3.14 \mathrm{~b}$ & $13.55 \mathrm{~b}$ & $11.73 \mathrm{~b}$ \\
\hline Spring & $7.61 \mathrm{~b}$ & $0.43 \mathrm{c}$ & $13.64 \mathrm{~b}$ & $5.94 \mathrm{c}$ \\
\hline Means & $8.40 \mathrm{~A}$ & $2.83 \mathrm{~B}$ & $15.01 \mathrm{~A}$ & $11.93 \mathrm{~B}$ \\
\hline
\end{tabular}

${ }^{1}$ Vertically, the average seasons planting within each growing condition followed by the same lowercase letters do not differ by Tukey test at $5 \%$ probability; ${ }^{2}$ Horizontally compares means between the growing environments for each variable, where the same capital letters do not differ by $\mathrm{F}$ test at $5 \%$ probability.

In the mountain conditions, no differences were observed between the planting seasons for rhizophore dry mass accumulation, however, higher accumulation of stem and tuberous root dry matter, and consequently total dry masses, were observed in the autumn planting. Notably, the dry mass of tuberous roots in the winter planting did not differ from that of the autumn planting. In the lowlands, decreasing values of stem, rhizophore, tuberous root and total dry mass accumulations were observed as planting approached the summer; thus, higher values were observed in the autumn planting than in the spring planting (Table 4). 
The yield of tuberous roots was affected by growing conditions, unlike the fresh mass of rhizophores, as higher yields of large, medium, and small tuberous roots were observed in the mountains, consequently giving a higher total yield (Table 5).

Table 5. Tuberous roots yield of yacon grown in two environments and three planting seasons.

\begin{tabular}{|c|c|c|c|c|}
\hline \multirow{2}{*}{$\begin{array}{l}\text { Planting } \\
\text { seasons }\end{array}$} & \multicolumn{4}{|c|}{ Growing environments } \\
\hline & Mountain & Lowland & Mountain & Lowland \\
\hline & \multicolumn{2}{|c|}{ Large $\operatorname{root}\left(\mathrm{Mg} \mathrm{ha}^{-1}\right)$} & \multicolumn{2}{|c|}{ Medium root $\left(\mathrm{Mg} \mathrm{ha}^{-1}\right)$} \\
\hline Autumn & $66.94 \mathrm{a}^{1}$ & $30.10 \mathrm{a}$ & $18.41 \mathrm{~b}$ & $24.35 \mathrm{a}$ \\
\hline Winter & $41.93 \mathrm{~b}$ & $9.59 \mathrm{~b}$ & $18.82 \mathrm{~b}$ & $10.30 \mathrm{~b}$ \\
\hline Spring & $14.88 \mathrm{c}$ & $0.00 \mathrm{c}$ & $34.18 \mathrm{a}$ & $0.00 \mathrm{c}$ \\
\hline \multirow[t]{2}{*}{ Means } & $41.25 \mathrm{~A}^{2}$ & $13.23 \mathrm{~B}$ & $23.80 \mathrm{~A}$ & $11.55 \mathrm{~B}$ \\
\hline & \multicolumn{2}{|c|}{ Small root $\left(\mathrm{Mg} \mathrm{ha}^{-1}\right)$} & \multicolumn{2}{|c|}{ Total $\left(\mathrm{Mg} \mathrm{ha}^{-1}\right)$} \\
\hline Autumn & $12.15 \mathrm{a}$ & $6.20 \mathrm{~b}$ & $97.50 \mathrm{a}$ & $60.65 \mathrm{a}$ \\
\hline Winter & $11.57 \mathrm{a}$ & $9.68 \mathrm{a}$ & $72.31 \mathrm{~b}$ & $29.57 \mathrm{~b}$ \\
\hline Spring & $13.54 \mathrm{a}$ & $4.42 \mathrm{~b}$ & $62.60 \mathrm{~b}$ & $4.42 \mathrm{c}$ \\
\hline Means & $12.42 \mathrm{~A}$ & $6.77 \mathrm{~B}$ & $77.47 \mathrm{~A}$ & $31.55 \mathrm{~B}$ \\
\hline
\end{tabular}

${ }^{1}$ Vertically, the average seasons planting within each growing condition followed by the same lowercase letters do not differ by Tukey test at $5 \%$ probability; ${ }^{2}$ Horizontally compares means between the growing environments for each variable, where the same capital letters do not differ by $\mathrm{F}$ test at $5 \%$ probability.

In mountain conditions, a higher yield of large tuberous roots was observed in the autumn planting thus contributing to a greater total yield also observed at this time of planting compared to winter and spring plantings. For medium roots, a higher yield was observed in the spring planting, and for the small roots, there was no difference in productivity between planting seasons (Table 5).

In the lowland, as well as for the biometric features discussed above, decreasing values of large, medium and total root yields were observed as planting approached the summer; thus, higher values were observed in the autumn planting and lower values in the spring planting, which only produced small roots. Only small root yield was greater in the winter planting (Table 5).

\section{DISCUSSION}

The lack of growth and satisfactory sprouts in summer planting, at both environmental conditions, are related to the adverse conditions to which the rhizophores were exposed. During the month of planting (December 2013), a heavy rainfall occurred $(551 \mathrm{~mm}$ and $483 \mathrm{~mm}$ in the mountain and lowland conditions, respectively; Figure 1) leaving the soil with excessive humidity. This moisture, combined with high temperatures (30 ${ }^{\circ} \mathrm{C}$ and $35{ }^{\circ} \mathrm{C}$ in the mountain and lowland conditions, respectively; Figure 1), caused the death of the rhizophores. This result indicates that cultivation of yacon in high temperature and soil humidity conditions (situations with heavy rain, for example) may pose risks for initial crop establishment.
Autumn planting, in mountain or lowland conditions, increases the plant height, stem diameter and biomass accumulation of yacon plants, which may have occurred due to higher crop cycles. Planting at this season also favoured biomass accumulation in yacon leaves, which consequently would be reflected in larger LAI since the numbers of leaves were similar. This result was also noted in all plants grown in the mountains, suggesting that under these conditions, plants produce larger leaves, which would increase their photosynthetic potential. In addition, increases in LAI improve the rate of photosynthetic capacity of plants (Galvani et al., 2000), promoting growth and development and resulting in productivity gains.

This behaviour is related to low temperatures during most of the cultivation cycle, which would be favourable for the development of yacon plants, since the species originates in the Andes, a region of high altitude and, consequently, with milder temperatures (Seminar et al., 2003). In general, when planting was carried out near summer, which has higher temperatures, a decrease in plant height, stem diameter and biomass accumulation was observed.

A relationship between temperature and yacon development is evident, since in the lowland condition where temperatures are higher, the plants showed lower performance mainly for the spring planting, paralyzing their growth during the summer. In this season, the lowland region showed high temperatures (approximately $35^{\circ} \mathrm{C}$ in January and February) even with rainfall volume similar to the mountain conditions (Figure 1). This demonstrates a sensitivity of yacon to heat stress 
from high temperature, contradicting Fernandez et al. (2006), which indicates that temperature during the cycle would be less relevant to its production.

Furthermore, the temperature during the cycle may change plant photosynthate allocation because under mild temperatures (such as in autumn planting or for crops in mountain conditions) there is low stem mass accumulation, including rhizophores, and more accumulation in tuberous roots, which directly influences crop yields since these roots are the main product of commercialization.

Similar behaviour was observed with yacon cultivated in the Andean region where altitudes between 1500 and $2000 \mathrm{~m}$ were better for the production of tuberous roots, while the coastal plains were better for the production of rhizophores (SEMINARIO et al., 2003).

Notably, yacon is vegetatively propagated, often through rhizophores. The presence of these structures are very important for the agricultural expansion of this crop; it even has been noted as the main reason that limits the expansion of this yacon in Brazil, mainly in the state of Espirito Santo. Thus, the yacon cultivation strategy in higher temperature conditions is rhizophore production, which will provide greater autonomy to farmers in relation to the propagation material.

The total productivity of tuberous roots, with exception of the spring planting in lowland conditions, approached or was above 25 and $35 \mathrm{Mg}$ $\mathrm{ha}^{-1}$ as observed in Korea (DOO et al., 2001), the Czech Republic (FERNANDEZ et al., 2006) and the United States (SUMIYANTO et al., 2012); 40 to 50 $\mathrm{Mg}$ ha $^{-1}$ was observed in Japan (OGISO et al., 1990), Ecuador (NIETO, 1991) and Peru (SEMINARIO et al., 2001) and $45 \mathrm{Mg} \mathrm{ha}^{-1}$ in Brazil (OLIVEIRA; NISHIMOTO, 2004). The highest total yield of tuberous roots was obtained with planting in the autumn (April) in both growing conditions $\left(97.50 \mathrm{Mg} \mathrm{ha}^{-1}\right.$ in mountain and 60.65 $\mathrm{Mg} \mathrm{ha}{ }^{-1}$ in lowland). Regardless of the time of planting, the highest yields were obtained in the mountain condition (average of $77.47 \mathrm{Mg} \mathrm{ha}^{-1}$ ).

As noted in vegetative development, temperature was also crucial for tuberization. This process is known to be influenced by mineral nutrition and the balance of endogenous regulators, and it is amended by photoperiod and temperature (FINGER et al., 2005). Yacon is described as neutral for photoperiod for stem and root formation (SEMINARIO et al., 2003), and once again the influence of temperature is evident as mild temperatures favoured the formation of tubers.
This characteristic has been noted in other plants with Andean origin, such as the potato (Solanum tuberosum), which has an optimum temperature for tuberization of approximately 17 ${ }^{\circ} \mathrm{C}$; temperatures above $30{ }^{\circ} \mathrm{C}$ affect potato tuberization (RODRÍGUEZ-FALCÓN et al., 2006), which seems to depend on changes in the levels of gibberellins and endogenous inhibitors (KERBAUY, 2013).

Observing temperatures during the crop cycle, for autumn planting in the mountain region, the temperature ranged between 13 and $25{ }^{\circ} \mathrm{C}$, which would be a great range for the development of yacon according to Seminario et al. (2003). Even in the spring planting in mountain conditions, temperatures during the cycle ranged between 15 and $28{ }^{\circ} \mathrm{C}$, which leads to higher dry matter accumulation and productivity of tuberous roots compared to the lowland condition.

Higher levels of phosphorus and potassium in the soil in the mountain region may also have contributed to the higher yields of the plants in that location, as showed by Fernandez et al. (2006); however, due to the very small difference between these levels, the contribution associated with temperature is believed to be the main contributing factor.

The choice of planting location and season also influences the pattern of harvested tuberous root, as with the autumn planting or crops in mountain conditions, there is higher productivity of large or medium-sized roots. This productivity means greater economic profitability given that these roots have higher market value.

In view of the foregoing, it is concluded that yacon cultivation in mountain conditions (tropical climate with milder temperatures) favours the development and production of yacon. Planting in the autumn in both growing conditions (mountain and lowland) promotes the development and production of yacon, including increased production of tuberous roots of better commercial grade, allowing greater economic profitability.

The results allow us to conclude that the temperature influenced the growth and yield of tuberous roots of yacon, with the milder temperatures being more favourable.

\section{ACKNOWLEDGEMENTS}

We thank Capes (Coordination of Improvement of Higher Education Personnel) for a $\mathrm{PhD}$ scholarship and $\mathrm{CNPq}$ (The National Council for Scientific and Technological Development) and FAPES (Foundation for Research Support and 
Innovation of Espírito Santo) for financial support. We also thank FAPES for the Capixaba researcher scholarship for the second author.

RESUMO: A yacon é um alimento funcional com grande potencial para exploração hortícola e seu cultivo exige a geração de informações agronômicas. Para atender a essas necessidades, este estudo foi realizado com o objetivo de avaliar a produção de yacon plantada em diferentes estações de plantio sob duas condições de crescimento no Brasil. Os experimentos foram conduzidos em dois locais diferentes, um em região montanhosa (microclima tropical de altitude com temperaturas mais amenas) e o outro em região de baixada (microclima tropical quente com temperaturas mais elevadas). Em ambos os locais, a yacon foi plantada em quatro estações: outono (abril), inverno (julho), primavera (setembro) e verão (dezembro). Por ocasião da colheita das raízes tuberosas foram avaliados o índice de área foliar e variáveis de desenvolvimento vegetativo e produtividade das plantas (raízes tuberosas totais e por padrão). Concluiu-se que o cultivo de yacon em condições de montanha (clima tropical com temperatura mais suave) promove melhor desenvolvimento e produção de yacon. Além disso, plantar no outono para ambas as condições de crescimento (montanha ou baixada) promove melhor desenvolvimento e produção de yacon, incluindo o aumento da produção de raízes tuberosas de melhor qualidade comercial, permitindo maior rentabilidade econômica. Estes resultados indicam que a temperatura influenciou o crescimento e o rendimento das raízes tuberosas de yacon e as temperaturas mais amenas foram mais favoráveis.

PALAVRAS-CHAVE: Smallanthus sonchifolius. Polymnia sonchifolia. Raíz tuberosa. Produtividade. Temperatura.

\section{REFERENCES}

ALBUQUERQUE, E. N.; ROLIM, P. M. Potencialidades do yacon (Smallanthus sonchifolius) no diabetes Mellitus. Revista Ciências Médicas, v. 20, n. 3-4, p. 99-108, 2011.

http://200.18.252.94/seer/index.php/cienciasmedicas/article/viewFile/584/564. https://doi.org/10.24220/23180897v20n3/4a584

CRUZ, C. D. Programa Genes: Biometria. Viçosa: Universidade Federal de Viçosa, 2006. 382 p.

DOO, H. S.; RYU, J. H.; LEE, K. S.; CHOI, S.Y. Effect of plant density on growth responses and yield in yacon. Korean Journal of Crop Science, v. 46, n. 5, p. 407-410, 2001.

http://www.cropbio.or.kr/journal/list.php

EMPRESA BRASILEIRA DE PESQUISA AGROPECUÁRIA [EMBRAPA]. Sistema brasileiro de classificação de solos. 4 th ed. Rio de Janeiro: Embrapa Solos - Centro Nacional de Pesquisa de Solos, 2014. $377 \mathrm{p}$.

FERNANDEZ, E. C.; VIEHMANNOVA, I.; LACHMAN, J.; MILELLA, L. Yacon [Smallanthus sonchifolius (Poeppig \& Endlicher) H. Robinson]: a new crop in the Central Europe. Plant Soil Environment, v. 52, n. 12, p. 564-570, 2006. https://doi.org/10.17221/3548-PSE

FINGER, F. L.; FONTES, P. C. R.; PAUIATTI, M. Dormência e tuberização. In: FONTES, P. C. R. (Ed.). Olericultura teoria e prática. Viçosa: Suprema Gráfica e Editora. 2005. p. 31-38.

GALVANI, E.; ESCOBEDO, J. F.; CUNHA, A. R.; KLOSOWSKI, E. S. Estimativa do índice de área foliar e da produtividade de pepino em meio protegido - cultivos de inverno e de verão. Revista Brasileira de Engenharia Agrícola e Ambiental, v. 4, n. 1, p. 8-13, 2000. http://dx.doi.org/10.1590/S141543662000000100002 
GENTA, S.B.; CABRERA, W. M.; HABIB, N.; PONS, J.; CARILLO, I. M.; GRAU, A.; SÁNCHEZ, S. S. Yacon syrup: beneficial effects on obesity and insulin resistance in humans. Clinical Nutrition, v. 28, n. 2, p. 182-187, 2009. https://doi.org/10.1016/j.clnu.2009.01.013

GUSSO, A. P.; MATTANNA, P.; RICHARDS, N. Yacon: benefícios à saúde e aplicações tecnológicas. Ciência Rural, v. 45, n. 5, p. 912-919, 2015. http://dx.doi.org/10.1590/0103-8478cr20140963 HABIB, N. C.; HONORÉ, S. M.; GENTA, S. B.; SÁNCHEZ, S. S. Hypolipidemic effect of Smallanthus sonchifolius (yacon) roots on diabetic rats: biochemical approach. Chemico-Biological Interactions, v. 194, n. 1, 31-39, 2011. https://doi.org/10.1016/j.cbi.2011.08.009

INSTITUTO CAPIXABA DE PESQUISA, ASSISTÊNCIA TÉCNICA E EXTENSÃO RURAL [INCAPER]. 2014. http://hidrometeorologia.incaper.es.gov.br/?pagina=bol

KAKIHARA, T. S.; CÂMARA, F. L. A.; VILHENA, S. M. C.; RIERA, L. Cultivo e industrialização de yacon (Polymnia sonchifolia): uma experiência brasileira. In: CONGRESSO LATINO AMERICANO DE RAÍZES TROPICAIS 1 E CONGRESSO BRASILEIRO DE MANDIOCA 9., 1996, São Pedro. Anais... Botucatu: Centro de Raízes Tropicais, Sociedade Brasileira de Mandioca, 1996. s.p.(resumo 148).

KERBAUY, G. Fisiologia Vegetal. 2. ed. Rio de Janeiro: Guanabara Koogan, 2013. 431 p.

LACHAN, L.; FERNÁNDEZ E.; ORSÁK, M. Saccharides of yacon [Smallanthus sonchifolius (Poepp. et Endl.) H. Robinson] tubers and rhizomes and factors affecting their content. Plant soil environment, Czech Republic, v. 50, n. 9, p. 383-390, 2004. https://doi.org/10.17221/4048-PSE

MAIER, R. J. Informações à Imprensa: Assessoria de Comunicação - Ceasa-ES, 2012. http:// www.faes.org.br/noticias_detalhe.php?Cod_Noticia=2283

MANRIQUE, I.; HERMANN, M. Yacon - Fact Sheet. Lima, Peru: International Potato Center (CIP), 2004. https: www.cipotato.org/artc/cipcrops/factsheetyacon.pdf

MOURA, N.A. DE; CAETANO, B. F. R.; SIVIERI, K.; URBANO, L. H.; CABELLO, C.; RODRIGUES, M. A. M.; BARBISAN, L. F. Protective effects of yacon (Smallanthus sonchifolius) intake on experimental colon carcinogenesis. Food and Chemical Toxicology, v. 50, n. 8, p. 2902-2910, 2012.

https://doi.org/10.1016/j.fct.2012.05.006

NIETO, C. C. Estudios agronomicos y bromatológicos em "jicama" (Polymnia sonchifolia Polp. Endl.). Archivos Lationoamericanos de Nutrición, v. 41, n. 2, p. 213-221, 1991.

OGISO, M.; NAITO, H.; KURASIMA, H. Planting density, harvesting time and storage temperature of Yercum. Research Bulletin of the Aichi Ken Agricultural Research Center, v. 22, p. 161-164, 1990.

OJANSIVU, I.; FERREIRA, C. L.; SALMINEN, S. Yacon, a new source of prebiotic oligosaccharides with a history of safe use. Trends in Food Science \& Technology, v. 22, n. 1, p. 40-46, 2011.

https://doi.org/10.1016/j.tifs.2010.11.005

OLIVEIRA, G. O.; BRAGA, C. P.; FERNANDES, A. A. H. Improvement of biochemical parameters in type 1 diabetic rats after the roots aqueous extract of yacon [Smallanthus sonchifolius (Poepp. \& Endl.)]. Food and Chemical Toxicology, v. 59, p. 256-260, 2013. https://doi.org/10.1016/j.fct.2013.05.050

OLIVEIRA, M. A.; NISHIMOTO, E. K. Avaliação do desenvolvimento de plantas de yacon (Polymnia sonchifolia) e caracterização dos carboidratos de reservas em HPLC. Brazilian Journal of Food Technology, v. 7, n. 2, p. 215-220, 2004.

PEZZOPANE, J. E. M.; CASTRO, F. S.; PEZZOPANE, J. R. M.; CECÍlIO, R. A. Agrometeorologia: aplicações para o Espírito Santo. Alegre: CAUFES, 2012. 174 p. 
RODRÍGUEZ-FALCÓN, M.; BOU, J.; PRAT, S. Seasonal control of tuberization in potato: conserved elements with the flowering response. Annual Review of Plant Biology, v. 57, p. 151-180, 2006. https://doi.org/10.1146/annurev.arplant.57.032905.105224

SANTANA, I.; CARDOSO, M. H. Raiz tuberosa de yacon (Smallanthus sonchifolius): potencialidade de cultivo, aspectos tecnológicos e nutricionais. Ciência Rural, v. 38, n. 3, p. 898-905, 2008.

http://dx.doi.org/10.1590/S0103-84782008000300050.

SEMINARIO, J.; VALDERRAMA, M.; MANRIQUE, I. El yacon: fundamentos para el aprovechamiento de un recurso promisorio. Lima: Centro Internacional de la Papa (CIP), Universidad Nacional de Cajamarca, Agencia Suiza para el Desarrollo y la Cooperación (COSUDE), 2003. 60 p.

SOLEIMANI, N.; HOSEINIFAR, S. H.; MERRIFIELD, D. L.; BARATI, M.; ABADI, Z. H. Dietary supplementation of fructooligosaccharide (FOS) improves the innate immune response, stress resistance, digestive enzyme activities and growth performance of Caspian roach (Rutilus rutilus) fry. Fish \& Shellfish Immunology, v. 32, n. 2, p. 316-321, 2012. https://doi.org/10.1016/j.fsi.2011.11.023

SUMIYANTO, J.; DAYAN, F. E.; CERDEIRA, A. L.; WANG, Y. H.; KHAN, I. A.; MORAES, R. M. Oligofructans content and yield of yacon (Smallanthus sonchifolius) cultivated in Mississippi. Scientia Horticulturae, v. 148, p. 83-88, 2012. https://doi.org/10.1016/j.scienta.2012.09.020

VAZ-TOSTES, M. G.; VIANA, M. L.; GRANCIERI, M.; LUZ, T. C. S.; PAULA, H.; PEDROSA, R.G.; COSTA, N. M. B. Yacon effects in immune response and nutritional status of iron and zinc in preschool children. Nutrition, v. 30, n. 6, p. 666- 672, 2014. https://doi.org/10.1016/j.nut.2013.10.016

ZERAIK, M. L.; PEREIRA, C. A. M.; ZUIN, V. G.; YARIWAKE, J. H. Maracujá: um alimento funcional? Revista Brasileira de Farmacologia, v. 20, n. 3, p. 459-471, 2010. http://dx.doi.org/10.1590/S0102695X2010000300026. 